\title{
Perbandingan Bagan Kendali Modifikasi Shewhart dan Bagan Kendali ARMAST pada ARMA $(1,1)$
}

\author{
Syandriana Syarifuddin ${ }^{1}$, Erna Tri Herdiana ${ }^{2}$, M. Saleh $\mathbf{A F}^{3}$
}

\begin{abstract}
Abstrak
Pada umumnya asumsi dasar untuk data pada bagan kendali adalah bersifat saling bebas dan menyebar normal. Namun tidak semua data dapat memenuhi asumsi tersebut salah satunya ketika terjadi autokorelasi. Jika terdapat autokorelasi pada data dapat mempengaruhi tingkat alarm palsu sehingga permasalahan autokorelasi perlu untuk diatasi. Cara untuk mengatasi data berautokorelasi pada bagan kendali dapat dilakukan dengan menggunakan bagan kendali modifikasi Shewhart dan bagan kendali ARMAST. Hasil penelitian menunjukkan pada bagan kendali ARMAST lebih sensitif terhadap data yang out of control dibandingkan dengan bagan kendali modifikasi Shewhart karena nilai ARL yang diperoleh pada bagan kendali ARMAST lebih kecil dibandingkan dengan ARL pada bagan kendali modifikasi Shewhart. Sehingga dalam penelitian ini disimpulkan bahwa performance bagan kendali ARMAST lebih baik dibandingkan bagan kendali modifikasi Shewhart.
\end{abstract}

Kata kunci: Autokorelasi, modifikasi Shewhart, ARMAST, ARL

\section{Pendahuluan}

Asumsi dasar penggunaan bagan kendali adalah data yang diperoleh bersifat saling bebas dan menyebar normal dengan nilai tengah $\mu$ dan ragam $\sigma^{2}$ dimana nilai $\mu$ dan $\sigma^{2}$ tetap [6].. Namun, dalam prakteknya tidak semua asumsi dapat terpenuhi salah satunya ketika proses yang terjadi bersifat autokorelasi. Jika terdapat autokerelasi pada data dapat mempengaruhi tingkat alarm palsu sehingga permasalahan autokorelasi ini perlu untuk diatasi [7]. Cara untuk mengatasi permasalahan autokorelasi pada bagan kendali yaitu dengan memodelkan menggunakan runtun waktu.

Beberapa peneliti telah menerapkan bagan kendali dengan model runtun waktu diantaranya yaitu Choirotunnisa (2014) meneliti pengaruh autokorelasi pada bagan kendali $\bar{x}$ dengan menggunakan model AR(1) diperoleh hasil sisaan model yang menyebar normal dan saling bebas menunjukkan bahwa tidak terdapat autokorelasi pada data dan proses terkendali. Hal ini berati bahwa model AR(1) dapat digunakan untuk memperbaiki pengaruh autokorelasi pada bagan kendali. Fitriani (2015) meneliti bagan kendali Cumulative Sum (CUSUM) untuk pengontrolan proses dengan model AR(1) diperoleh hasil pada bagan kendali Cumulative Sum (CUSUM) tradisional out of control lebih cepat terdeteksi dibandingkan dengan bagan kendali Cumulative

\footnotetext{
${ }^{1}$ Syandriana022@gmail.com, ${ }^{2}$ herdiani.erna@gmail.com, ${ }^{3}$ afsaleh54@yahoo.co.id
}

1,2,3 Program Studi Statistika, Departemen Matematika FMIPA, Universitas Hasanuddin 
Sum (CUSUM) untuk pengontrolan proses dengan model AR(1) hal ini karena bagan kendali Cumulative Sum (CUSUM) tadisional underestimate.

Pada sebagian besar penelitian mengenai bagan kendali yang menggunakan model runtun waktu data yang sering digunakan yaitu data berpola AR(1) sedangkan dalam permasalahan autokorelasi dapat saja ditemukan data dengan pola yang lain. Misalkan, jika suatu data memiliki pola $\operatorname{ARMA}(1,1)$. Jika data berpola $\operatorname{ARMA}(1,1)$ pengaruh autokorelasi dapat diatasi dengan menggunakan bebrapa bagan kendali yang dimodelkan dengan $\operatorname{ARMA}(1,1)$. Untuk mengatasinya dapat dilakukan dengan menggunakan bagan kendali modifikasi Shewhart dan juga bagan kendali ARMAST yaitu bagan kendali ARMA yang mengalami autokorelasi [10]. Sehingga pada penelitian ini bertujuan membandingkan kinerja bagan kendali modifikasi Shewhart dan bagan kendali ARMAST pada data ARMA $(1,1)$.

\section{Tinjauan Pustaka}

\subsection{Model ARMA $(p, q)$}

Bentuk umum untuk ARMA $(p, q)$ dapat dinyatakan dalam persamaan

$$
\dot{X}_{t}=\phi_{1} X_{t-1}+\phi_{2} X_{t-2}+\cdots+\phi_{p} X_{t-p}+a_{t}-\theta_{1} a_{t-1}-\theta_{2} a_{t-2}-\cdots-\theta_{q} a_{t-q}
$$

Sehingga bentuk umum untuk model $\operatorname{ARMA}(1,1)$ dapat dinyatakan dalam persamaan

dengan:

$$
\dot{X}_{t}=\phi_{1} X_{t-1}+a_{t}-\theta_{1} a_{t-1}
$$

$\theta_{1}=$ parameter-parameter moving average ke 1

$a_{t-1}=$ nilai kesalahan pada saat $t-1$

$a_{t}$ adalah proses white noise dengan $a_{t} \sim N\left(0, \sigma^{2}\right)$

$\phi_{1}=$ parameter autoregresi ke-1

$\dot{X}_{t}=X_{t}-\mu$

[9]

\subsection{Autokorelasi}

Autokorelasi menyatakan hubungan antara variabel yang sama dengan waktu yang berbeda sehingga terdapat perbedaan antara korelasi dan autokorelasi. Korelasi yaitu mengukur hubungan linier antara dua buah variabel yang berbeda sedangkan autokorelasi mengukur hubungan linier antara variabel yang sama dengan waktu yang berbeda [9]

Fungsi Autokorelasi atau Autocorrelation Function (ACF) adalah suatu fungsi yang menunjukkan besarnya korelasi antara pengamatan waktu ke-t dengan pengamatan pada waktu yang sebelumnya. Fungsi autokorelasi menunjukkan koefisien autokorelasi yang merupakan pengukuran korelasi antara observasi pada waktu yang berbeda [3].

Fungsi autokorelasi parsial (partial autocorrelation function) digunakan untuk mengukur tingkat keeratan antara $X_{t}$ dan $X_{t-k}$, apabila pengaruh dari lag waktu (time lag) dianggap terpisah [1].

Tabel 1. Ciri-ciri teoritis ACF dan PACF untuk proses stasioner

\begin{tabular}{ccc}
\hline Model & ACF & PACF \\
\hline AR(p) & $\begin{array}{l}\text { Turun secara eksponensial atau } \\
\text { membentuk gelombang sinus }\end{array}$ & Terpotong setelah lag $\mathrm{p}$ \\
& \\
\hline
\end{tabular}




\section{Syandriana Syarifuddin, Erna Tri Herdiana, M. Saleh AF}

MA(q) Terpotong setelah lag q
Turun secara eksponensial atau

membentuk gelombang sinus

\begin{tabular}{lll}
\hline $\operatorname{ARMA}(\mathrm{p}, \mathrm{q})$ & Turun cepat setelah lag $(\mathrm{q}-\mathrm{p})$ & Turun cepat setelah $\operatorname{lag}(\mathrm{p}-\mathrm{q})$ \\
\hline
\end{tabular}

Sumber : Wei, 2006

\subsection{Kestasioneran}

Box dan Jenkins (1976) menjelaskan bahwa pada deret waktu yang bersifat stasioner kuat, waktu pengamatan tidak berpengaruh terhadap rata-rata $\mu$, variansi $\sigma^{2}$, dan kovariansi $\gamma_{k}$. Ini berarti bahwa deret $X_{t}$ akan berfluktuasi disekitar $\mu$ dan variansi $\sigma^{2}$ yang tetap, dan dapat dikatakan bahwa deret $X_{t}$ stasioner dalam $\mu$ dan $\sigma^{2}$ [9].

Pemeriksaan kestasioneran suatu data dapat digunakan diagram runtun waktu (time series plot) yaitu diagram pencar antara nilai peubah $X_{t}$ dengan waktu t. Jika diagram berfluktuasi disekitar garis yang sejajajar sumbu waktu (t) maka dikatakan data stasioner dalam rata-rata [1]. Grafik suatu data yang stasioner dapat dilihat pada Gambar 2.4 dan yang tidak stasioner dapat dilihat pada Gambar 2.5

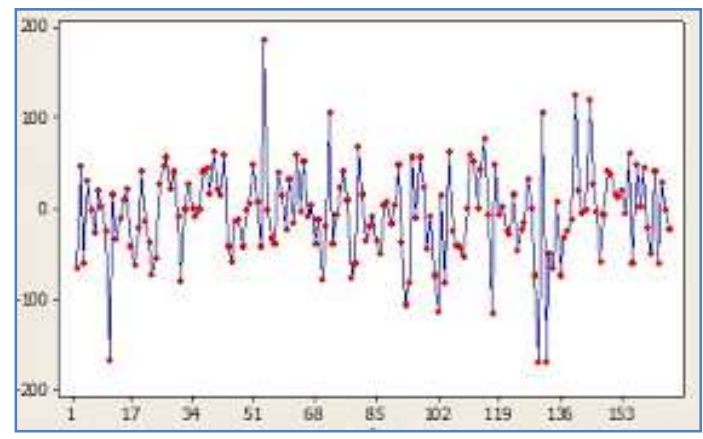

Gambar 1. Plot Time Series Stasioner

(Sumber: Aswi dan Sukarna, 2006)

Pemerikasaan kestasioneran suatu data dapat juga menggunakan uji unit root. Uji unit root yang biasa digunakan adalah uji augmented Dickey-Fuller. Uji lain yang serupa yaitu uji PhillipsPerron. Keduanya mengindikasikan keberadaan unit root sebagai hipotesis nol.

Pengujian augmented Dickey-Fuller

Hipotesis

$H_{0}: \delta=0$ (data tidak stasioner)

$H_{1}: \delta \neq 0$ (data stasioner)

Statistik uji

$t=\frac{\widehat{\delta}-\delta}{S E(\hat{\delta})}$

Daerah Kritis

$\alpha=0.05$

Kriteria keputusan: 


\section{Syandriana Syarifuddin, Erna Tri Herdiana, M. Saleh AF}

$H_{0}$ ditolak jika $\left|t_{\text {hit }}\right|>t_{\frac{\alpha}{2}, n-1}$

[8].

Suatu proses yang stasioner $\left\{X_{t}\right\}$ mempunyai sifat:

1. Mean $X_{t}$ yaitu $\mathrm{E}\left(X_{t}\right)=\mu$

2. Variansi $X_{t}$ yaitu $\operatorname{Var}\left(X_{t}\right)=\mathrm{E}\left(X_{t}-\mu\right)^{2}=\sigma^{2}$

3. Covariansi $X_{t}$ yaitu $\operatorname{Cov}\left(X_{t}, X_{t+k}\right)=\gamma_{k}$ (fungsi dari perbedaan waktu

$$
\gamma_{k}=\operatorname{Cov}\left(X_{t}, X_{t+k}\right)=\mathrm{E}\left(X_{t}-\mu\right)\left(X_{t+k}-\mu\right)
$$

4. Korelasi antara $X_{t}$ dan $X_{t+k}$ (autokorelasi)

$$
\rho_{k}=\frac{\operatorname{Cov}\left(X_{t}, X_{t+k}\right)}{\sqrt{\operatorname{Var}\left(X_{t}\right) \operatorname{Var}\left(X_{t+k}\right)}}=\frac{\gamma_{k}}{\gamma_{0}}
$$

\subsection{White Noise Process}

Suatu proses $\left\{a_{t}\right\}$ dinamakan white noise process (proses yang bebas dan identik) jika bentuk peubah acak yang berurutan tidak saling berkorelasi dan mengikuti distribusi tertentu [9]. Suatu white noise process $\left\{a_{t}\right\}$ adalah stasioner dengan beberapa sifat berikut:

$$
\mathrm{E}\left(a_{t}\right)=\mu_{a}=0 \quad, \operatorname{Var}\left(a_{t}\right)=\sigma_{a}^{2} \quad \text { dan } \quad \gamma_{k}=\operatorname{cov}\left(a_{t}, a_{t+k}\right)=0 \text { untuk } k \neq 0
$$

Fungsi autovariansi:

Fungsi autokorelasi:

$$
\gamma_{k}= \begin{cases}\sigma_{a}^{2}, & \text { untuk } k=0 \\ 0, & \text { untuk } k \neq 0\end{cases}
$$

Fungsi autokorelasi parsial

$$
\rho_{k}= \begin{cases}1, & \text { untuk } k=0 \\ 0, & \text { untuk } k \neq 0\end{cases}
$$

Langkah pengujian ljung-Box:

$$
\phi_{k k}= \begin{cases}1, & \text { untuk } k=0 \\ 0, & \text { untuk } k \neq 0\end{cases}
$$

1. Hipotesis

$H_{0}: r_{1}=r_{2}=\cdots=r_{k}=0$ ( Tidak ada korelasi pada residu $)$

$H_{1}$ : Minimal terdapat satu $r_{k} \neq 0$, untuk $k=1,2,3, \ldots, K$ (Ada korelasi pada residu )

2. Statistik uji yang digunakan adalah statistic Ljung-Box yaitu

$$
Q_{K}=n(n+2) \sum_{k=1}^{K} \frac{r_{k}^{2}}{n-k}
$$

dengan $n$ adalah banyaknya observasi, $K$ adalah banyaknya lag yang diuji, $r_{k}$ adalah nilai koefisien autokorelasi pada lag- $k$.

3. Kriteria keputusan: Tolak $H_{o}$ jika $\mathrm{Q}>\chi_{\alpha ; d f}^{2}$ dengan $d f=k-p$ [9].

\subsection{Pengujian Signifikansi Parameter}

Pada runtun waktu setelah diperoleh dugaan model awal dengan melihat plot ACF dan PACF selanjutnya dilakukan uji signifikansi parameter. Uji signifikan parameter dapat dilakukan dengan langkah-langkah berikut:

1. Hipotesis 


\section{Syandriana Syarifuddin, Erna Tri Herdiana, M. Saleh AF}

$H_{0}: \theta=0$ dan $\phi=0$ (parameter tidak signifikan)

$H_{1}: \theta \neq 0$ dan $\phi \neq 0$ (parameter signifikan)

2. Statistik uji yang digunakan dapat dilihat pada persamaan

$$
t=\frac{\widehat{\theta}}{S E(\widehat{\theta})} \text { dan } t=\frac{\widehat{\phi}}{S E(\widehat{\phi})}
$$

3. Kriteria keputusan: $H_{0}$ ditolak jika

$$
\left|t_{\text {hit }}\right|>t_{\frac{\alpha}{2}, n-1}
$$

2.6 Pemilihan Model Terbaik

Pemilihan model terbaik dapat dilakukan dengan membandingkan nilai Mean Square Error (MSE). Mean Square Error (MSE) adalah suatu kriteria pemilihan model terbaik berdasarkan pada hasil sisa peramalan. Persamaan dari Mean Square Error yaitu

$$
M S E=\frac{1}{n} \sum_{i=1}^{n}\left(\hat{X}_{i}-X_{i}\right)^{2}
$$

Semakin kecil nilai Mean Square Error yang dihasilkan berarti model yang dipilih semakin baik.

\subsection{Bagan Kendali Shewhart}

Misalkan w sebagai sampel statistik yang akan diukur kualitasnya dengan nilai mean $\mathrm{w}$ adalah $\mu_{w}$ dan standar deviasi $\mathrm{w}$ adalah $\sigma_{w}$ maka UCL, CL, LCL pada bagan kendali shewhart sebagai berikut:

$$
\begin{gathered}
U C L=\mu_{w}+L \sigma_{w} \\
C L=\mu_{w} \\
L C L=\mu_{w}-L \sigma_{w}
\end{gathered}
$$

$\mathrm{L}$ adalah jarak batas kontrol dari garis tengah, dinyatakan dalam unit standar deviasi [6]. Nilai L pada umumnya yaitu 1, 2, dan 3. Semakin besar nilai L menunjukkan semakin lebar batas suatu bagan kendali

\subsection{Average Run Length}

Kriteria yang digunakan untuk dapat membandingkan bagan kendali adalah dengan mengukur seberapa cepat diagram kontrol tersebut membangkitkan sinyal out of control. Bagan kendali yang lebih cepat mendeteksi sinyal out of control disebut lebih sensitif terhadap perubahan proses [5]. Salah satu cara untuk mengukur kinerja diagram kontrol adalah dengan menggunakan Average Run Length (ARL). Average Run Length (ARL) adalah jumlah rata-rata titik sampel yang harus di plot pada bagan kendali sebelum suatu titik menunjukkan keadaan tak terkendali (out of control) [6]. Semakin kecil ARL, semakin cepat grafik kendali mendeteksi adanya pergeseran. Persamaan ARL yaitu :

$$
A R L=\frac{1}{P(\text { suatu titik diluar kendali })}
$$

atau

$$
A R L_{1}=\frac{1}{1-\beta}
$$




\section{Syandriana Syarifuddin, Erna Tri Herdiana, M. Saleh AF}

\section{Metode Analisis}

Jenis data yang digunakan terdiri atas dua data yaitu data simulasi dan data asli. Data simulasi yaitu berupa data yang dibangkitkan dengan menggunakan program $R 3.4 .3$ sebanyak 500 data dan 5.000 data. Data yang dibangkitkan berupa data yang berdistribusi normal dengan nilai mean 0 dan nilai variansi 1. Data asli yaitu data Inflasi Bulanan Indonesia Januari 2005 -Desember 2017 diperoleh dari Badan Pusat Statistika.

Tahapan yang dilakukan dalam penelitian ini adalah sebagai berikut:

Tahap I menggunakan data simulasi

1. Menentukan rumus mean dan variansi

2. Menentukan rumus bagan kendali bagan kendali modifikasi Shewhart dan ARMAST untuk data $\operatorname{ARMA}(1,1)$

3. Membangkitkan data ARMA(1,1) dengan menggunakan persamaan $X_{t}=\phi X_{t-1}+a_{t}-\theta a_{t-1}$ dengan nilai mean $a_{t}=0$ dan nilai variansi $a_{t}=1$

4. Menguji kestasioneran data yang telah di bangkitkan

5. Mengestimasi Parameter, mendiagnostik model, dan menentukan model terbaik dari data yang telah dibangkitkan untuk membuktikan data yang telah di bangkitkan memiliki model $\operatorname{ARMA}(1,1)$

6. Menghitung nilai bagan kendali moifikasi Shewhart dan bagan kendali ARMAST untuk model data ARMA $(1,1)$

7. Membandingkan performance bagan kendali modifikasi Shewhart dan ARMAST pada data $\operatorname{ARMA}(1,1)$ dengan melihat nilai ARL

Tahap II menggunakan data asli

1. Menguji kestasioneran data

2. Mengestimasi Parameter, mendiagnostik model, dan menentukan model terbaik dari data yang telah dibangkitkan untuk membuktikan data yang telah di bangkitkan memiliki model $\operatorname{ARMA}(1,1)$

3. Menghitung nilai mean dan nilai variansi residual dari data

4. Menghitung nilai bagan kendali Moifikasi Shewhart dan bagan kendali ARMAST untuk data $\operatorname{ARMA}(1,1)$

5. Membandingkan performance bagan kendali modifikasi Shewhart dan ARMAST pada data $\operatorname{ARMA}(1,1)$ dengan melihat hasil UCL dan LCL

4. Hasil dan Pembahasan

4.1 Penentuan Bagan kendali Modifikasi Shewhart

bentuk umum Autoregressive Moving Average (ARMA) ordo $(1,1)$ atau ARIMA $(1,0,1)$ yaitu

$$
\dot{X}_{t}=\phi \dot{X}_{t-1}+a_{t}-\theta a_{t-1}
$$

Dalam penentuan bagan kendali $\operatorname{ARMA}(1,1)$ terlebih dahulu ditentukan mean dan variansi $\operatorname{ARMA}(1,1)$. Dari hasil penelitian diperoleh mean $\mu$ dan variansi $\frac{\left(1-2 \theta \phi+\theta^{2}\right) \sigma_{a}^{2}}{\left(1-\phi^{2}\right)}$ Sehingga bagan kendali Shewhart pada ARMA $(1,1)$ adalah 


\section{Syandriana Syarifuddin, Erna Tri Herdiana, M. Saleh AF}

$$
\begin{aligned}
U C L & =\mu+L \sqrt{\frac{\left(1-2 \theta \phi+\theta^{2}\right) \sigma_{a}^{2}}{\left(1-\phi^{2}\right)}} \\
C L & =\mu \\
L C L & =\mu-L \sqrt{\frac{\left(1-2 \theta \phi+\theta^{2}\right) \sigma_{a}^{2}}{\left(1-\phi^{2}\right)}}
\end{aligned}
$$

\subsection{Penentuan Bagan Kendali ARMAST}

Bagan kendali Autoregressive Moving Average untuk data yang mengalami autokorelasi disebut dengan ARMAST. Dimana $Z_{t}$ adalah data yang berautokorelasi. Dengan rumus korelasi $\rho(\tau)=\frac{\gamma(\tau)}{\gamma(0)}$ dan rumus kovariansi $\gamma(\tau)=\operatorname{cov}\left(Z_{t}, Z_{t-\tau}\right)$. Sehingga bentuk umum model Autoregressive Moving Average (ARMA) dapat dinyatakan sebagai berikut:

dengan $\alpha=\phi \theta_{0}-\theta$ dan $\theta_{0}=1+\theta-\phi$

$$
Z_{t}=\theta_{0} X_{t}+\alpha \sum_{k=1}^{t-1} \phi^{k-1} X_{t-k}
$$

Dalam menentukan bagan kendali terlebih dahulu ditentukan mean dan variansi dari bagan kendali ARMA. Dari hasil penelitian diperoleh mean $\mu$ dan variansi $\sigma_{z}^{2}=\left\{\theta_{0}^{2}+\frac{\alpha^{2}}{1-\phi^{2}}+2\left(\theta_{0} \alpha+\right.\right.$ $\left.\left.\frac{\phi \alpha^{2}}{1-\phi^{2}}\right) \frac{\rho(1)}{1-\phi u}\right\} \sigma_{X}^{2}$

dengan

$$
\begin{aligned}
& \rho(1)=u-v \frac{\sigma^{2}}{\sigma_{X}^{2}} \\
& \sigma_{z}^{2}=\left\{\theta_{0}^{2}+\frac{\alpha^{2}}{1-\phi^{2}}+2\left(\theta_{0} \alpha+\frac{\phi \alpha^{2}}{1-\phi^{2}}\right) \frac{\rho(1)}{1-\phi u}\right\} \sigma_{X}^{2} \\
& u=\phi \\
& v=\frac{\theta}{\theta_{0}}
\end{aligned}
$$

Sehingga diperoleh bagan kendali ARMAST $(1,1)$ yaitu

$$
\begin{aligned}
U C L & =\mu_{Z}+L \sqrt{\left\{\theta_{0}^{2}+\frac{\alpha^{2}}{1-\phi^{2}}+2\left(\theta_{0} \alpha+\frac{\phi \alpha^{2}}{1-\phi^{2}}\right) \frac{\rho(1)}{1-\phi u}\right\} \sigma_{X}^{2}} \\
C L & =\mu_{Z} \\
L C L & =\mu_{Z}-L \sqrt{\left\{\theta_{0}^{2}+\frac{\alpha^{2}}{1-\phi^{2}}+2\left(\theta_{0} \alpha+\frac{\phi \alpha^{2}}{1-\phi^{2}}\right) \frac{\rho(1)}{1-\phi u}\right\} \sigma_{X}^{2}}
\end{aligned}
$$

\subsection{Studi Kasus I}

Pada bab ini akan dibangkitkan data $\operatorname{ARMA}(1,1)$ yaitu 500 dan 5.000 data dengan menggunakan $R$ 3.4.3 yang memiliki nilai error $\left(a_{t}\right)$ beproses white noise dengan nilai mean $a_{t}=$ 0 , nilai variansi $a_{t}=1, \theta=0,4$. dan $\phi=0,6$. 


\subsubsection{Bagan Kendali}

Berdasarkan hasil perhitungan nilai UCL, CL, dan LCL dengan menggunakan persamaan (1) diperoleh bagan kendali modifikasi Shewhart pada ARMA(1,1) untuk data 500 yaitu $\mathrm{UCL}=3,013309, \mathrm{CL}=-0,07902$, dan $\mathrm{LCL}=-3,17135$. Dengan menggunakan persamaan (2) diperoleh hasil bagan kendali ARMAST yaitu $\mathrm{UCL}=2,347735, \mathrm{CL}=-0,07902$, dan $\mathrm{LCL}=-2,505775$.

Hasil perhitungan bangan kendali pada 5000 diperoleh nilai bagan kendali modifikasi Shewhart yaitu $\mathrm{UCl}=3,08925, \mathrm{CL}=-0,00308$ dan $\mathrm{LCL}=-3,0954$. Nilai bagan kendali ARMAST yaitu $\mathrm{UCl}=2,423685, \mathrm{CL}=-0,00308$ dan $\mathrm{LCL}=-2,4298255$. Secara visual grafik bagan kendali pada $\mathrm{n}=500$ dan $\mathrm{n}=5.000$ dapat dilihat pada Gambar 2 dan Gambar 3

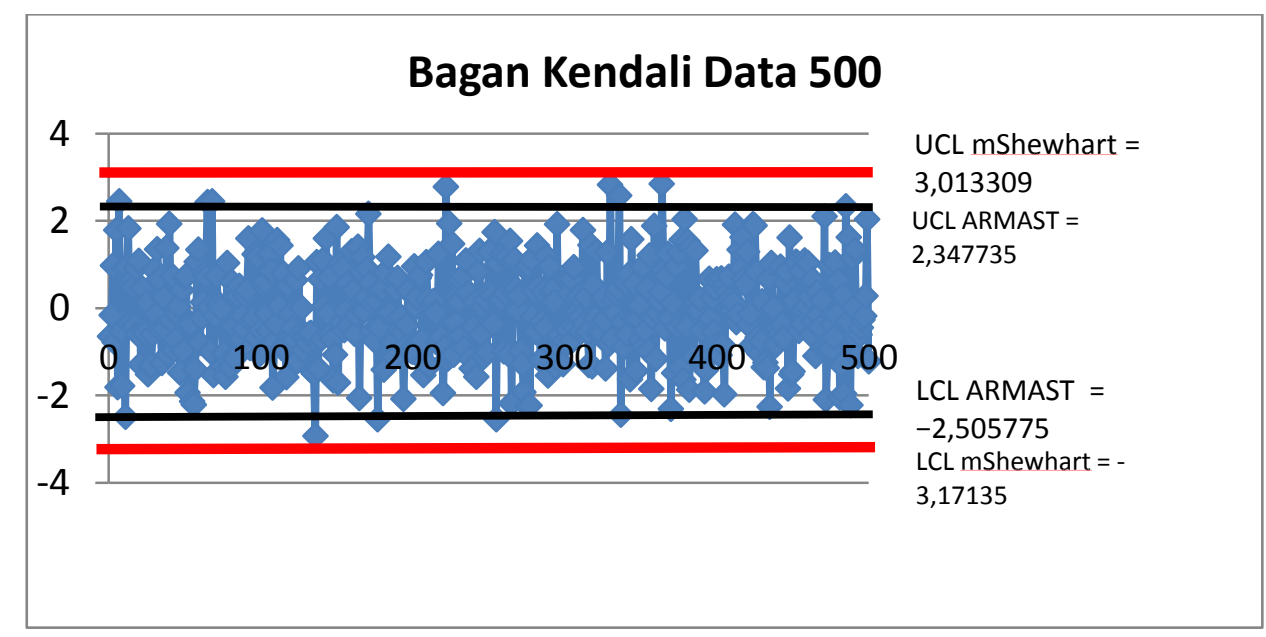

Gambar 2. Bagan Kendali Data 500

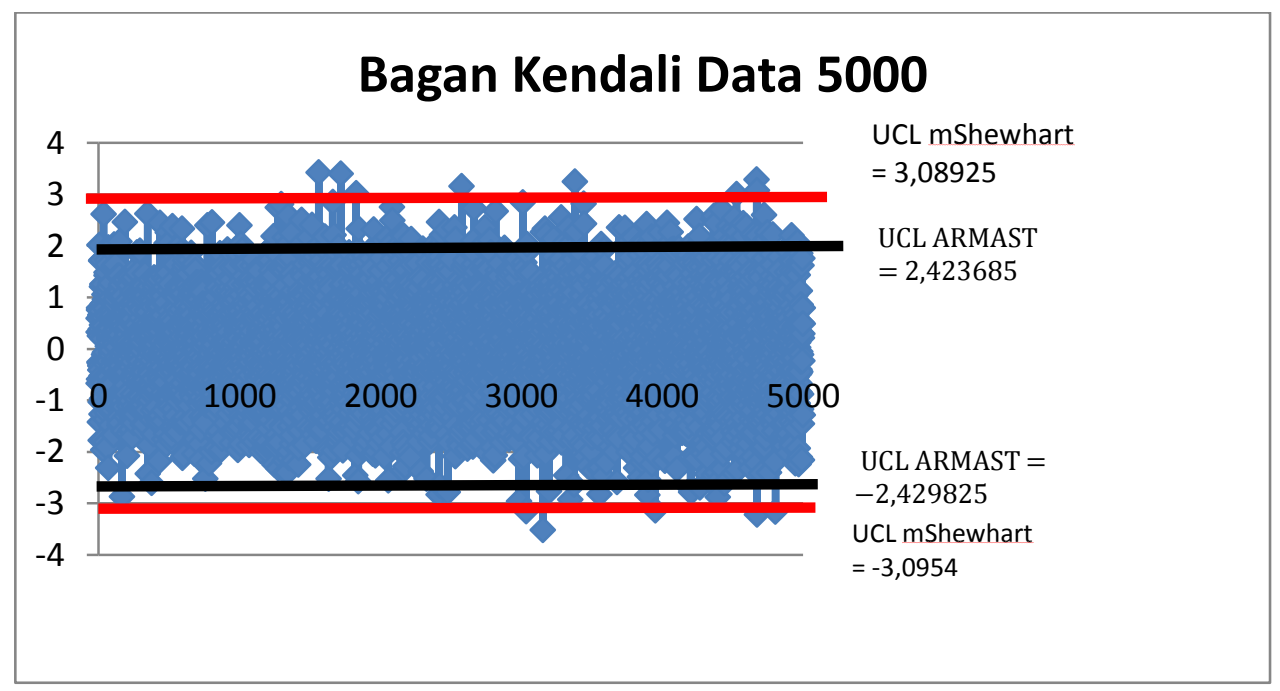

Gambar 3. Bagan Kendali Data 5000 


\section{Syandriana Syarifuddin, Erna Tri Herdiana, M. Saleh AF}

\subsubsection{Perhitungan Average Run Length}

Untuk mengetahui performance dari suatu bagan kendali dapat dilakukan dengan melihat nilai Average Run Length (ARL). Semakin kecil ARL, semakin cepat grafik kendali mendeteksi adanya pergeseran. Dengan bantuan software $R$ 3.4.3 didapatkan nilai ARL yang dapat dilihat pada Tabel 2

Tabel 2. Nilai ARL

\begin{tabular}{ccccc}
\hline \multirow{2}{*}{ Shift } & \multicolumn{2}{c}{ MShewhart } & \multicolumn{2}{c}{ ARMAST } \\
\cline { 2 - 5 } & $\mathrm{n}=500$ & $\mathrm{n}=5.000$ & $\mathrm{n}=500$ & $\mathrm{n}=5.000$ \\
\hline 0 & 35,084 & 34,7054 & 16,3600 & 15,8240 \\
\hline 0,5 & 22,264 & 21,0928 & 12,0760 & 10,4736 \\
\hline 1 & 9,872 & 9,8720 & 5,7300 & 5,4636 \\
\hline 2 & 2,730 & 2,7300 & 2,0040 & 1,8272 \\
\hline 4 & 1,064 & 1,0160 & 1,0000 & 1,0054 \\
\hline
\end{tabular}

Sumber: Data diolah, 2018

Berdasarkan Tabel 2 nilai ARL untuk shift 0 pada bagan kendali modifikasi Shewhart dengan $\mathrm{n}=500$ adalah 35,084 dan pada bagan kendali ARMAST adalah 16,3600. Berdasarkan hasil nilai ARL menunjukkan untuk shift 0 nilai ARL dari bagan kendali ARMAST jauh lebih kecil dibandingkan bagan kendali modifikasi Shewhart. Pada nilai shift 0,5, 1, 2, dan 4 untuk $\mathrm{n}=5000$ juga menunjukkan nilai ARL bagan kendali ARMAST lebih kecil dibandingkan bagan kendali modifikasi Shewhart.

Untuk $\mathrm{n}=5.000$ pada shift 0 nilai ARL bagan kendali modifikasi Shewhart adalah 34,7054 dan pada bagan kendali ARMAST adalah 15,8240. Hal ini menunjukkan untuk shift 0 dengan $\mathrm{n}=$ 5.000 nilai ARL dari bagan kendali ARMAST jauh lebih kecil dibandingkan bagan kendali modifikasi Shewhart. Pada nilai shift $0,5,1,2$, dan 4 untuk $n=5.000$ juga menunjukkan nilai ARL bagan kendali ARMAST lebih kecil dibandingkan bagan kendali modifikasi Shewhart.

\subsection{Studi Kasus II}

Pada bab ini digunakan data Inflasi Bulanan Indonesia Januari 2005 - Desember 2017

\subsubsection{Uji Kestasioneran Data}

Sebelum melakukan identifikasi model terlebih dahulu dilakukan uji kestasioneran. Untuk mengetahui data telah stasioner atau tidak dapat dilihat pada grafik data. Dapat dilihat pada Gambar 4. 


\section{Syandriana Syarifuddin, Erna Tri Herdiana, M. Saleh AF}

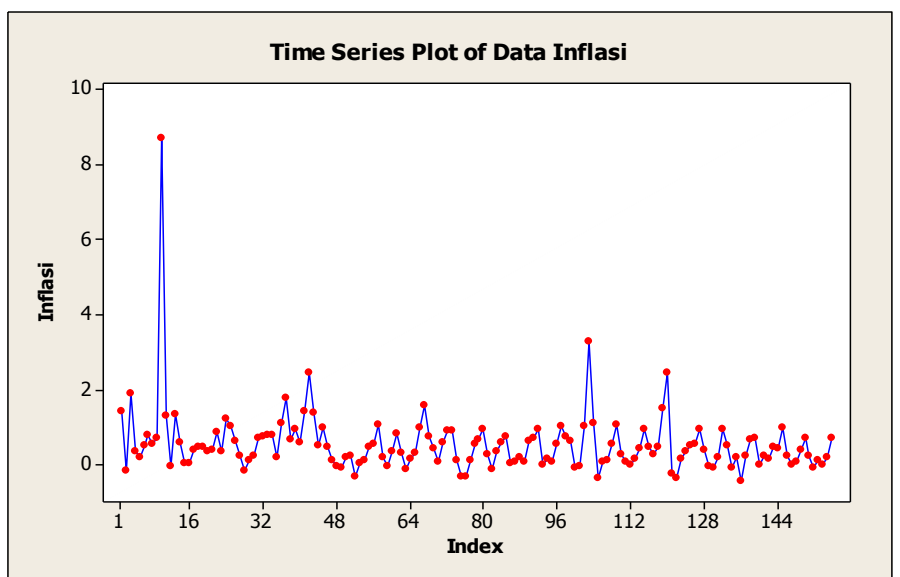

Gambar 4. Grafik Data Inflasi Bulanan

Berdasarkan Gambar 4 menunjukkan data tidak mengalami trend naik ataupun trend turun tetapi berada di sekitaran rata-rata hal ini berarti data telah stasioner. Selain dengan grafik dapat dilakukan uji kestasioneran data dengan uji ADF. Dengan menggunakan bantuan software R 3.4.3 didapatkan hasil pengujian untuk data yaitu Dickey-Fuller $=-5.1329$, Lag order $=5$, p-value $=$ 0.01 . Karena nilai p-value $<0.05$ sehingga $H_{0}$ ditolak yang berarti data stasioner.

\subsubsection{Identifikasi model ARIMA}

Untuk menetukan dugaan model ARIMA dapat dilakukan dengan melihat pada plot ACF dan PACF. Dapat dilihat pada Gambar 5.

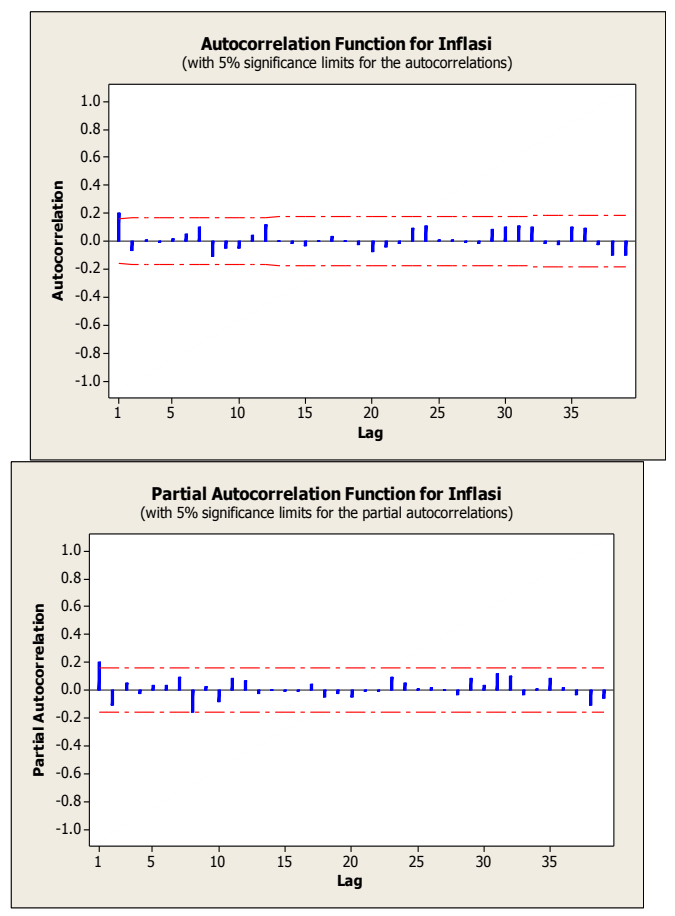

Gambar 5. Plot ACFdan PACF Data Inflasi Bulanan 


\section{Syandriana Syarifuddin, Erna Tri Herdiana, M. Saleh AF}

Berdasarkan Gambar 5 menunjukkan pada grafik ACF terjadi cut off pada lag 1 dan pada grafik PACF menunjukkan terjadi cut off pada lag 1 sehingga didapatkan beberapa dugaan model. Dapat dilihat pada Tabel 4.4.

Tabel 3. Hasil Estimasi Parameter

\begin{tabular}{ccccc}
\hline Model & \multicolumn{2}{c}{ Parameter } & p-value & MSE \\
\hline ARMA(1,1) & AR(1) & $-0,5818$ & 0,001 & 0,702 \\
& MA(1) & $-0,71917$ & 0,000 & \\
\cline { 2 - 4 } & Konstanta & 0,8513 & 0,000 & \\
\hline \multirow{2}{*}{ AR(1) } & AR(1) & 0,2005 & 0,012 & 0,714 \\
& Konstanta & 0,4305 & 0,000 & \\
\hline \multirow{2}{*}{ MA(1) } & MA(1) & $-0,2497$ & 0,002 & 0,707 \\
\cline { 2 - 4 } & Konstanta & 0,53894 & 0,000 & \\
\hline
\end{tabular}

Sumber: Data diolah, 2018

Berdasarkan Tabel 3. pada semua dugaan model nilai MSE terkecil berada pada model $\operatorname{ARMA}(1,1)$ yaitu 0,702 dan semua parameter $\operatorname{ARMA}(1,1)$ signifikan. Sehingga dapat disimpulkan model data jumlah orang yang dimakamkan adalah ARMA $(1,1)$ dengan parameter $\mathrm{AR}=-0,5818$ dan $\mathrm{MA}=-0,71917$.

\subsubsection{Uji White Noise}

Hasil nilai statististik Ljung-Box untuk pengujian white noise dapat dilihat pada Tabel 4.5

Tabel 4. Hasil Ljung-Box

\begin{tabular}{cccc}
\hline Lag & $\chi^{2}$ & DF & p-value \\
\hline 12 & 7,6 & 9 & 0,577 \\
\hline 24 & 12,2 & 21 & 0,935 \\
\hline 36 & 20,6 & 33 & 0,955 \\
\hline 48 & 30,3 & 45 & 0,955 \\
\hline
\end{tabular}

Sumber: Data diolah, 2018

Nilai statistik Ljung-Box pada lag 12 menunjukkan nilai statistik antara lag t dengan lag 12. Pada Tabel 4. menunjukkan bahwa pada lag 12 nilai p-value aadalah 0,577>0,05 yang berarti tidak cukup bukti untuk menolak $H_{0}$ sehingga diperoleh kesimpulan yaitu tidak ada korelasi antara residual pada lag t dengan residual pada lag 12. Untuk lag 24, 36, dan 48 nilai p-value > 0,05 artinya antara sisaan pada lag t dan pada lag 24, 36, dan 48 tidak ada yang saling berkorelasi. Karena tidak ada yang mengalami korelasi sehingga dapat disimpulkan residual telah memenuhi syarat white noise.

\subsubsection{Bagan Kendali}

Berdasarkan hasil perhitungan nilai UCL, CL, dan LCL dengan menggunakan persamaan (1) diperoleh bagan kendali modifikasi Shewhart pada $\operatorname{ARMA}(1,1)$ untuk data 500 


\section{Syandriana Syarifuddin, Erna Tri Herdiana, M. Saleh AF}

yaitu $\mathrm{UCL}=3,1151311, \mathrm{CL}=0,5367$, dan $\mathrm{LCL}=-2,04167$. Dengan menggunakan persamaan (2) diperoleh hasil bagan kendali ARMAST yaitu UCL $=3,064118, \mathrm{CL}=0,5367$, dan LCL $=-2,04167$. Secara visual dapat dilihat pada Gambar 6 .

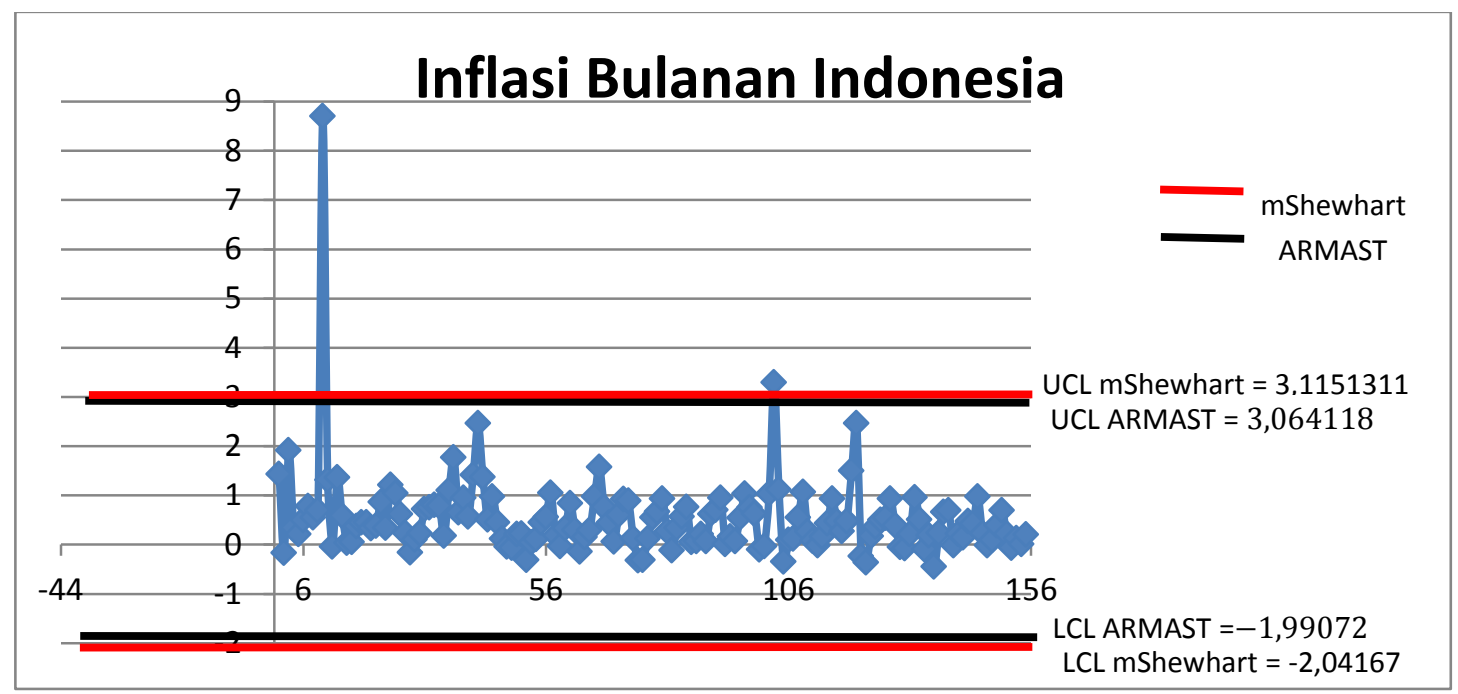

Gambar 6. Bagan Kendali Inflasi Bulanan Indonesia

Secara visual pada Gambar 6. menunjukkan pada kedua bagan kendali terdapat dua data yang keluar dari bagan kendali yaitu pada bulan Oktober 2005 dan Juli tahun 2017. Jika dibandingkan bagan kendali modifikasi Shewhart dan ARMAST maka didapatkan bagan kendali modifikasi Shewhart lebih lebar dibandingkan bagan kendali ARMAST. Hal ini mengindikasikan bahwa ARMAST lebih sensitif terhadap data out of control dibandingkan dengan modifikasi Shewhart.

\section{Kesimpulan}

Berdasarkan penelitian terhadap data yang berpola $\operatorname{ARMA}(1,1)$ pada data simulasi diperoleh bagan kendali modifiksi Shewhart lebih lebar dibandingkan bagan kendali ARMAST. Untuk data Inflasi Bulanan Indonesia Januari 2005 hingga Desember 2017 diperoleh Bagan kendali Shewhart adalah $U C L=3,1151311, C L=0,5367$ dan $L C L=-2,04167$ dan Bagan kendali ARMAST adalah $U C L=3,064118, C L=0,5367$, dan $L C L=-1,99072$. Berdasarkan hasil bagan kendali pada data Inflasi Bulanan Indonesia Januari 2005 hingga Desember 2017 juga menunjukkan bagan kendali modifikasi Shewhart lebih lebar dibandingkan bagan kendali ARMAST. Hal ini mengindikasikan bahwa ARMAST lebih sensitif terhadap data out of control dibandingkan dengan modifikasi Shewhart. Berdasarkan nilai ARL diperoleh hasil nilai ARL bagan kendali ARMAST lebih kecil dibandingkan dengan bagan kendali modifikasi Shewhart Sehingga dapat disimpulkan performance bagan kendali ARMAST lebih baik dibandingkan dengan modifikasis Shewhart. 


\section{Syandriana Syarifuddin, Erna Tri Herdiana, M. Saleh AF}

\section{DAFTAR PUSTAKA}

[1] Aswi dan Sukarna. 2006. Analisis Deret Waktu : Teori Dan Aplikasi. Makassar : Andhira Publisher.

[2] BPS. 2018. Indeks Harga Konsumen dan Inflasi Bulanan Indonesia. dari www.bps.go.id: https://www.bps.go.id/statictable/2009/06/15/907/indeks-harga-konsumen-dan-inflasi bulanan-indonesia 2005-2017.html

[3] Cryer, D.J. 1986. Time Series Analysis. Boston: PWS-KENT Publishing Company

[4] Dawod, A. B. 2016. On Model Selection for Autocorrelated Processes in Statistical Process Control. Quality and Reability Engineering International, 33(4): 867-882

[5] Fitriani, A. 2014. Diagram Kontrol Cumulative Sum Untuk Pengontrolan Proses dengan Model Autoregresive Orde Pertama (AR(1)) [skripsi]. Bandung: Universitas Islam Bandung.

[6] Montgomery, C. Douglas. 2009. Statistical Quality Control (6th ed). Asia: John Wiley \&Sons (Asia) Pte. Ltd.

[7] Padgett, C.S., Thombs L.A. and Padgett, W. J. 1992. On the QUOTE -risk for Shewhart Control Chart. Comunication in Statistics, Simulation, and Computation. 21: 1125-1147.

[8] Rusdi. 2011. Uji Akar-Akar Unit dalam Model Runtun Waktu Autoregresif. Forum Teori dan Aplikasi Statistika , 11(2): 67-78.

[9] Wei, William, W.S. 2006. Time series Analysis: Univariate and Multivariate Methods,. 2nd Edition. USA: Pearson Educations, Inc.

[10] W. Jiang, K.L. Tsui, and W.H. Woodall. 2000. A new SPC monitoring method: The ARMA chart. Technometrics.42(4): 399-410. 